\title{
The Auckland MA Sociology (Option II - Social Welfare and Development): A social work qualification gone but not forgotten
}

\author{
Barbara Staniforth
}

\begin{abstract}
INTRODUCTION: The University of Auckland MA in Sociology (Option II-Social Welfare and Development) ("the Programme") was a qualifying social work programme that admitted students from 1975 to 1979 . This article describes this programme and some of the issues that led to its short-lived tenure.

METHODS: Semi-structured interviews were conducted with 12 staff and students who had been involved with this programme. One person, involved in the accreditation of the Programme was also interviewed, and one person provided feedback in an email. Information was also obtained through archived University of Auckland documents, reports, and various forms of personal correspondence provided by June Kendrick.
\end{abstract}

FINDINGS: The Programme was championed by the Head of the Department of Sociology (David Pitt). There were resource limitations and philosophical tensions within the Department about the qualification. There was little support for its continuation at the end of a three-year grant and after the departure of David Pitt. The New Zealand Social Work Training Council accredited it after its discontinuation.

CONCLUSION: The Programme made a valuable contribution to the profession of social work and social work education and forms an important part of the history of social work in Aotearoa New Zealand.

KEYWORDS: social work qualification; education; New Zealand; history

AOTEAROA

NEW ZEALAND SOCIAL WORK 30(2), 42-56.

CORRESPONDENCE TO: Barbara Staniforth

b.staniforth@auckland.ac.nz

\section{Introduction}

There has been, over time, some attention paid to documenting the history of various aspects of social work education in Aotearoa New Zealand. John McCreary described the first postgraduate qualifying social work programme at Victoria University in his two-part series, Martians and Minions (1971a, 1971b) and John Crockett completed his thesis (in the MA Sociology described in this article) on "Social Work Education in New Zealand" in 1977. John Cranna documented his accounts of the social work programme at the Auckland College of Education (1989). Mary Nash completed her PhD thesis on the topic (1998) and has written many other chapters (see, for example, Nash, 2001) and articles on social work history. McDonald (2004) wrote about 
the relationship of social work education and the professional association, while the author of this article has recently written about the social work training programmes provided through the State Services Commission at Tiromoana and Taranaki House (Staniforth, 2015). Most recently, van Heugten and Gibbs (2015) have provided a historical account of the relationships of social work and sociology within an international context, and Harington (2016) has written about the sometimes uneasy relationship of sociology and social work in Aotearoa, outlining some aspects which are familiar to this programme and that are discussed in this article.

In the description of the evolution of social work education in Aoteroa New Zealand, there are often accounts that social work education programmes had begun at Victoria University in 1949-1950, with programmes following at Massey University and Canterbury University in 1976. Mention, but little detail, is given to the brief-lived social work masters qualification provided through the University of Auckland (1975-1980). While authors such as Nash (1998) have explored this qualification, there does not appear to be any comprehensive presentation about this programme in the literature.

This article uses a social constructivist lens to piece together different facts, opinions and accounts about the MA Sociology (Option-II Social Welfare and Development). The process of conducting the research is described, with a description of the content and structure of the Programme following. Possible reasons for the discontinuation of the Programme are explored, with impressions from interview participants provided to add colour to the historical documents.

\section{Methodology}

The approach to the research was interpretivist and socially constructionist (Bryman, 2016). The "data" were produced through individuals' experiences of the Programme, and the author's interpretations of their accounts and the historical

documents that she was privy to.

There were three main sources used to write this article. These included previous interviews with June Kendrick, a tutor in the Programme, historical documents, and more recent interviews with staff, students and others who had interactions with the Programme.

Initial accounts of the MA Sociology Option II were provided through recorded interviews with June Kendrick, in 2006, for the author's doctoral thesis (Staniforth, 2010) and in 2011 for an historical article written about Kendrick (Staniforth \& Nash, 2012). Kendrick later gave written permission, in 2015, for information from these two interviews to be used for this article.

Written information was obtained through the University of Auckland Library. A librarian provided access to locatable documents in relation to the Programme. A detailed account of the search process was not made available. The bulk of the information came in the form of documents, reports, minutes, and personal correspondence provided to the author by Kendrick, from her time in the Programme.

Consent for this research was obtained from the University of Auckland Human Participants Ethics Committee in 2014. An email invitation was sent out to members of the Aotearoa New Zealand Association of Social Workers (ANZASW) requesting that they make contact with the researcher if they were interested in learning more about the research. Three participants made contact, with two subsequently engaging in interviews. All other interviewees were approached directly, either because they were known to have been involved with the Programme, or had been suggested by other interviewees. Three staff involved in the Programme were interviewed, as were seven previous students (three via Skype, four in person). One person from the New Zealand Social Work Training Council (NZSWTC) accreditation board was interviewed and 
one previous fieldwork supervisor provided information via email.

Semi-structured interviews were audio recorded, with notes taken by the author throughout the interviews. Relevant quotations were transcribed from the interviews and participants were given the opportunity to either be identified or to remain anonymous. All quotations were approved by participants prior to publication.

\section{The Programme}

The MA Sociology (Option II-Social Welfare and Development) began at The University of Auckland within the Department of Sociology in 1975 and took in its final intake of students in 1979. This was only the second social work qualification in the country to emerge since the establishment of the Victoria University Post Graduate Diploma in Social Sciences in 1949-1950.

Brian Manchester, who was a member of the Social Work Training Council in the 1970s, described the beginnings of the Programme:

At that time there were very few trained social workers in the field and Victoria University of Wellington was the only educational institution offering qualifying courses at tertiary level and the number graduating each year was small...The catchment area of greatest unmet need was the greater Auckland area but the University of Auckland did not seem ready to respond.

Representations to the Professor of Sociology at The University of Auckland [David Pitt], who for a time was a member of our Council, resulted ultimately in a short lived course at Masters level, called if my memory serves me correctly an "MA in Social Welfare and Development".

(B. Manchester, personal communication, January 29, 2011)

Professor David Pitt, who sat for a time on the Social Work Training Council (Department of Sociology, 1976) was described by several interviewees as "entrepreneurial" and was acknowledged as having championed the Programme into the Department of Sociology. From its beginnings, there was contention as to the nature of the Programme. Existing sociology staff within the Department believed that they were approving a traditional Master's degree in social welfare and development. In a memorandum to the Vice-Chancellor on 8 October, 1979 Vodanovich (acting Head of Department) explained:

The M.A in Sociology Option II (Social Welfare and Development) as it was proposed and accepted by the Faculty on 4/4/1974 (App. I) had as its primary objective the training of supervisors, administrators and policy makers. (p. 1)

The degree however, would soon be presented as a professional qualifying social work degree. In a set of guidelines written for students in 1975, the purpose of the degree was described, "The degree is intended to be a two year professional training for social workers and others working in social welfare institutions in New Zealand and the Pacific" (Pitt, 1979, p. 1).

Later, in a memorandum (November 13, 1979) from Kendrick to then Acting Head of Department, Vodanovich, Kendrick described the degree as having been designed to:

(a) recognise an academic performance at MA level with provision for graded pass and the award of appropriate honours; (b) provide a first qualification for social work practice.

(p. 1)

Just as the Victoria University programme did not have the term social work in its qualification, the same applied in this instance. Manchester described one of the reasons for this: "On one occasion I had asked Professor Pitt why, what I understood was to be a social work practitioner course had been given such a vague title as 'Master of Social Welfare and Development.' 
His response was 'because social work is regarded as somewhat disreputable amongst my academic colleagues'" (B. Manchester, personal communication, February 6, 2006).

The Calendar Prescription (see Table 1) describes a two-year postgraduate programme comprised of course work, field practicum and a thesis requirement.

A student from the first intake described that "there were about 10 people. At least one person straight from sociology" (anonymous, personal communication, June 18, 2015). The Programme began in the Rexcourt Building on Symonds Street. "We got started without much preparation. There was no room for grad students, and there were hardly any books" (anonymous, personal communication, June 18, 2015).

Initially there were no additional lecturing staff employed in the Department of Sociology to undertake the coordination or delivery of this Programme. In 1976, Pamela Ringwood, who was also employed with the Faculty of Law, was brought onto the Programme in a half-time capacity to teach law and social work into the Programme. In 1977, June Kendrick was welcomed to the Department. Kendrick came to the Department "though the generosity of a grant of \$15,000 from Mobil Oil New Zealand Limited to support graduate teaching and research in social welfare and development" (Department of Sociology, 1977, p. 1). This grant provided for a three-year tenure.

It would appear that there were somewhere between 10 and 15 students admitted to the Programme each year of its five intakes (1975: 10; 1976: unknown; 1977: 10; 1978: 15; 1979: 11). The majority of students came with a background of a Bachelor of Arts in Sociology, followed by Psychology, and then a range of subjects such as Anthropology, History, Education and English. While the Programme was intended to take two years full time, records revealed that many students completed the Programme on a part-time basis, often taking up to four years.

Pitt, guest lecturers, tutors and other Department of Sociology staff, took classes prior to the arrival of Ringwood and Kendrick. Several of the interviewees

Table 1. Calendar Prescription 1977

Option II: Sociology (Social Welfare and Development)

Four papers and a thesis which counts as two papers and a practical placement which counts as one paper, or in exceptional cases, where a placement cannot be arrange[d] to the satisfaction of the Head of the Department, four papers and a thesis which counts as three papers.

Candidates for Sociology (Social Welfare and Development) will normally be graduates (with social welfare papers) or have a degree in social work. With approval from Senate, graduates from subjects other than sociology, e.g. Anthropology and Political Studies, may be admitted.

All students must take 82.500 and 82.501 , and [at] least one paper from 82.502 to 82.506 . In consultation with the Head of Department [an] additional paper may be taken from the 82.300 or 82.400 series or with the approval of the relevant Head of Department [from] other prescribed courses. The papers may be spread over two years. The thesis shall not exceed 20,000 words in length. A report not exceeding 10,000 words shall be submitted on the practical placement. The placement will be arranged by the Department in an approved agency or institution and will normally be undertaken concurrently with the theoretical studies. At the discretion of the Head of Department a candidate may be examined orally on either or both the subject of his thesis or placement report.

Students intending to enrol in 1977 are asked to consult the Head of Department about their course before enrolment. 


\section{QUALITATIVE RESEARCH}

82.500 The Principles of Social Work and Social Administration
82.501 Social and Community Work Methods
82.502 Social Development and Social Services in New Zealand
82.503 Social Development and Social Services in Asia and the Pacific
82.504 Human Growth and Development
82.505 Special Topic to be prescribed by the Head of the Department
82.506 Special Topic to be prescribed by the Head of the Department

Source: The University of Auckland (1977, p. 202).

recalled a seminar orientation to classes in the early years of the Programme.

Colin Jones, one of the later-year students, provided his impression of the classes:

$\mathrm{He}$ [Pitt] oversaw a fairly brief period on social policy. My recollection was that he didn't deliver a single lecture. He presented us on the first day with a series of topics, told us to choose one and go away and prepare to give a seminar on that topic. I felt sorry for those who were up first who didn't have a lot of time to prepare. (Personal communication, June $15,2015)$

John Crockett, an earlier student, had a different perspective:

David was committed to a tutorial model where the seminar was important. "This is a theme, let's talk about it". He was encouraging intellectual freedom, but at the same time holding quite a high standard in assessment and intellectual rigour in that regard. (J. Crockett, personal communication, November 27, 2015)

Some of these seminar themes from 1979 are presented in Table 2.

\section{Staffing the Programme}

With a lack of staff dedicated to teaching social work initially, Pitt appeared to be working hard to hold the new programme together.

He [Pitt] did the course on shoe string. He gathered people from here, there, and everywhere. It looked like it [the Programme] was always under threat. His vision held it together. It was an exciting vision. He was an exciting lecturer. (J. Crockett, personal communication, November 27, 2015)

Table 2. Seminar Themes, 1979

The history of child welfare often follows a cyclical pattern between institutional and family care. Discuss this
with special reference to adoption, fostering, residential and day care.
Penal services may aggravate rather than correct deviance. Discuss.
"The casework approach to poverty and income maintenance is nothing but a waste of time. It is society and
not the individual that must be changed." Evaluate this statement.
Social welfare and social work have traditionally acted as agents against social change. Explore the
alternatives and draw conclusions about the application of social work principles to general sociological
theory.

Source: Course outline 82.500 The Principles of Social Work and Social Administration (Department of Sociology, 1979b). 
Dr Ivanica Vodanovich, who was lecturing within the Sociology Department and eventually became interim Head of School when Pitt left the University in 1979, recalled that there were many guest lecturers that Pitt was able to bring in, particularly from Victoria University (I. Vodanovich, personal communication, April 7, 2016). Ringwood and Kendrick would provide the substantive social work content to the Programme.

Kendrick came to the University with a background of education and social work with her most recent position having been supervising social worker at Auckland Hospital (Staniforth \& Nash, 2012). Kendrick recalled that "the position was held out to me that my job would be to be lecturer in social work, but also to take responsibility for the placement and any follow up" (personal communication, July 28, 2006). Vodanovich recalled that "... [w]ith June, it became more social work focused and that's what students wanted. Students saw themselves, and June saw herself, as teaching social work" (personal communication, April 7, 2016).

The hosting of Professor Ben Schlesinger, a Visiting Professor from the University of Toronto from July 1978 to 1979 , was a highlight for staff and students. (Department of Sociology, 1979a). This undoubtedly provided quite a useful input of social work academic experience and knowledge into the Programme. Cluny Macpherson, a lecturer in sociology in the Department at the time, described how Schlesinger was able to bridge some of the social work-sociology divide while he was there (personal communication, January 27, 2016), while Stewart, a student at the time, acknowledged the status which Schlesinger brought to social work, "he was a professor of social work and they had never seen someone like that before" (personal communication, January 13, 2016).

\section{Content and structure}

As demonstrated within the Course Calendar earlier, there were few courses to choose from, with a fairly proscribed programme: O'Flaherty, a student in the Programme remembered, "There was not much variety in terms of courses. Most of us did what was on offer. We all did all the core things. Couldn't be lots on offer with those [low] numbers" (personal communication, May 26, 2016). Table 3 presents course descriptions for 1975. By 1979, with Kendrick on board, the 82.500 course had evolved slightly. Table 4 covers material from lectures in 1979.

Table 3. Course descriptions 1975

82.500 Principles of Social Work and Social Administration
Modules will include theories of social work, history of social work, fields of social work, marriage and family,
child welfare and youth care, geriatric problems, housing and environment, medical social work and health
services, disabilities and handicaps, mental health services, correctional services, poverty and income
programmes, contemporary trends and future directions.
82.501 Methods of Social and Community Work
Individual casework, counselling methods, group work, community work, social work amongst special
groups, Polynesian, elderly, deviants, social work as a vocation, ethical problems.

Source: Pitt (1975, p. 2).

Situated within a sociology department, the courses appeared to have a strong sociological perspective, especially in the earlier years. "I am pleased that I did the course. It opened my eyes to sociological, feminist, Marxist theory, reality theory" (Anonymous, personal communication, June 18, 2015). 


1. Social Work Function
a) Defining the Task-Consideration of the Report Prepared by the British Association of Social Workers
b) Social Workers and their Role in Society-Social change and social control operating within the "Social
Welfare System".
c) Philosophy Of Social Work
2. History of Social Work
a) Changing Perspectives In Relation To Social Work Theory
b) Current Philosophy of Social Work Practice
c) Some Theories of Social Work Casework. The "Helping Process".
3. Role of the Social Worker in Relation to Other Professions and Agencies
4. Working in a Bureaucracy.

Source: Department of Sociology (1979b).

Crockett explained his hopes for the course:

I was wanting skills, professional skills. My main intention was to be better at my job. [Pitt had a] sociological approach. He was keen to see social work in its wider context and of its effects on society. I think he was ahead of me in that regard. It took me a while to get that perspective. I was looking at things more narrowly... psychological-skills based... I now regard him as quite a visionary. (Personal communication, November 27, 2015)

Jill Goldson had begun the social work programme at Victoria University and then transferred to study at Auckland. She recalled: "There was a political push in the curriculum that I respected. Looking at it now I think that it was pretty good, it was quite grunty, compared to Wellington that was much more 'touchy feely'. Overall it was quite intense" (J. Goldson, personal communication, August 22, 2015).

Lynda Court (nee Jaffe) felt that the curriculum "was a mainstream approach to supporting people ... it covered everything that it should in terms of a social work course then. It had all the basics. I became a good social worker"

(personal communication, December 2, 2015).

The practical experience was what differentiated option I versus option II of the
MA. As is still often the case, the practicum presented the Programme with some of its greatest challenges and the students with some of their greatest opportunities.

\section{Practicum}

Students were required to complete a "practical placement and a 10,000 word report which counted as one paper" (NZSWTC, July 1981, p. 1). Students completed more than 1,000 hours and often completed their placement in more than one setting.

In a 1979 (November 13) memorandum to then Acting Head of School, Dr Ivanica Vodanovich, Kendrick described her initiation into the practicum component: "When I joined the staff in 1977, with special responsibility for the oversight and arranging of placements, I found a confused and generally unsatisfactory situation" (p. 1).

The yearly Department Annual Reports also demonstrated some of the shifting sands under which the placements occurred:

From the 1976 Annual Report:

1976 also saw the opening of the two student units at Greenlane/National Women's and Kingseat Hospitals. Miss M. Somerville, and Mrs. M. Lawrence were appointed as respective supervisors. (p. 1) 
From the 1977 Annual Report:

During the year there was continuation of the two student units for the MA (Option ii) through [sic] we were sorry to say goodbye to Miss M. Somerville and Mrs. M. Lawrence who had acted as supervisors. (p. 1)

From the 1978 Annual Report:

The student units for the MA (Option ii) were plagued with staffing shortages during the year but a new unit was established with the Department of Social Welfare. (p. 1)

From the 1979 Annual Report: In April, three field work teachers, funded by the Departments of Health and Social Welfare-Diane Naftel, Peter Pascoe and Griff Richards-were appointed to supervise the practical placements of the students enrolled in the M.A. Option II. (1979a, p. 1)

Peter Pascoe was one of the people appointed to work as a student supervisor through the Department of Social Welfare. He reiterated some of the difficulties with supporting the placements described previously by Kendrick:

I enjoyed my two years as a Student Unit Supervisor/Fieldwork Teacher despite being totally without organisational support, either from the Department or the University. However we 3 student unit supervisors-[myself and] Griff Richards, Diane Naftel—all worked together very well. (Personal communication, June 1, 2016)

As demonstrated by the Department Annual Reports, the student units were short-lived. Kendrick wrote to Vodanovich, in the November 1979 memo, that:

The present situation-where we have no intake of Government bursars (and possible non-intake of other students in 1980), our teaching staff reduced to one temporary lecturer whose appointment terminates in June of 1980, and no person in charge of the course, mean[s] that we are very vulnerable to criticism (if not worse) from the public agencies that have funded field-work units in good faith that we will use them. (p. 3)

\section{Placements}

Students undertook their placements in a variety of settings and spoke positively of their experiences.

I did one placement at Kingseat Hospital in the alcoholic unit. There were some good and bad experiences which also fitted in with some of the theory we did ... around stigmatising and labelling effects. I was seeing that straight out. (J. Crockett, personal communication, November 27, 2015)

I did two placements: Greenlane Hospital in the cancer ward and a community work placement at Pakuranga Community Centre, with the City Council where I did a survey of the needs of the area. Two very good placements. Greenlane was excellent: I worked with a lot of patients who were dying of cancer using Kubler Ross' work. (R. Stewart, personal communication, January 13, 2016)

My first placement was at National Women's Hospital. There's nothing like getting thrown in to a department with all its madness. I was given clients, went up to wards, spoke to women ... My second placement was at probation. I absolutely loved that, working with first offenders. I had 13 clients. It was fantastic. My second placement was particularly memorable, especially in terms of learning about how to connect with involuntary clients. (L. Court, personal communication, December 2, 2015)

While students enjoyed their placements, there was some concern from them, as well 
as from Kendrick, around the structure surrounding assessment of placements.

One of the anomalies of the placement was that there were no marked assessments of the students' practice abilities, with completion of the required hours, and production of a 10,000 word report being the only requirements. While supervisors provided some feedback, there was no formal assessment procedure for students' time in the field.

Pascoe (Student Unit Supervisor) offered some insight into this lack of formal assessment:

Griff, Diane and I spent a great deal of time developing written protocols for student placement assessment. After doing all this work we were very upset when the sociology lecturers said that the degree was an academic one and they would not accept that student placements were to be assessed... Griff, Diane and I had some very heated meetings with the sociology lecturers at staff meetings. (P. Pascoe, personal communication, June 1, 2016)

While there were some difficulties with finding and supervising placements, a strength of the Programme was the research component expected of all students.

\section{Theses}

A 20,000-word supervised thesis was a required component of the course. Supervision was sometimes difficult to obtain, as there were few lecturers in the Department of Sociology and even fewer who felt willing or able to supervise practical social work research.

We had a Social Work Professor: Schlesinger, whose forte was on one-parent families and he was my supervisor for my thesis on prisoner's wives and their families. Half way through Professor Schlesinger had to leave. They wanted me to change the thesis to be based on sociological theory. (R. Stewart, personal communication, January 13, 2016)

Students often completed the thesis after they had left the University campus and finished other coursework. This sometimes made it difficult to maintain momentum: "I was discussing the thesis with a sociology lecturer who had no knowledge of social work. I was looking at role of CYF social worker.... Once I got back to work it was almost impossible to focus (Anonymous, personal communication, June 18, 2015).

Table 5 provides a list of the theses undertaken during the Programme's duration. These represent a significant contribution to early social work research in Aotearoa New Zealand.

\section{Discontinuation}

One of the mysterious elements surrounding this qualification was its very short existence. The first intake of students occurred in 1975 and the last in 1979. There were many views surrounding potential reasons for this, which came out in the interviews and, when put together, they created a picture of faculty in the Sociology Department who were unaware of what they were signing up to deliver, a lack of resources to deliver it with, and the person with the vision to deliver it leaving soon after the Programme's establishment.

Macpherson and Vodanovich both recounted the way that the Programme had been introduced into the Department. Ivanovich remembered that the Programme had originally been touted as an MA in Social Welfare and Social Development. "We went along with it at the beginning as we thought it was social development, but it evolved quickly into a professional social work qualification" (I. Vodanovich, personal communication, April 7, 2016). 


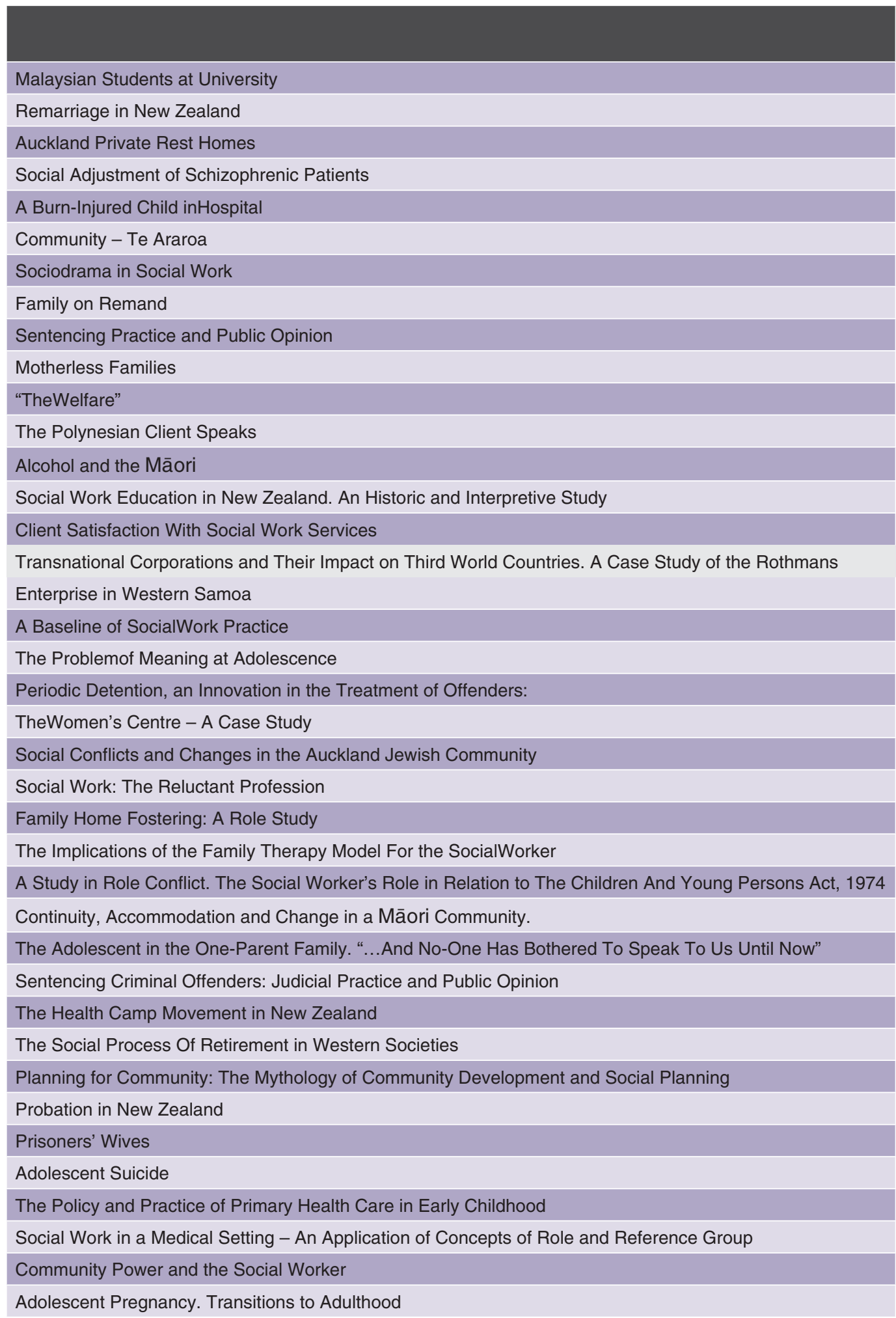

Source: Personal communication provided by June Kendrick (n.d.). 
David Pitt was a free agent ... David assumed we would be happy with anything he did. He announced without consultation that one of the major fuel companies had agreed to sponsor a social work programme for 3 years and to provide a chair. We were all completely taken aback... (C. Macpherson, personal communication, January 16, 2016)

Pascoe, working within the student unit, also saw this: "It became clear that Pitt had developed this course without the support of the staff of the Sociology Department of which he was head. This was an obvious recipe for disaster. And so it was not surprising when the course folded very quickly" (P. Pascoe, personal communication, June 1, 2016).

There were other philosophical tensions that existed for the degree being housed in the Department of Sociology. Macpherson described these clearly:

Most of us had a very strong socialist thread running through a lot our teaching, even if we weren't in fact Marxists. We were committed to a socialist ideal. The idea that we were going to harbour a group of people who would disguise the flaws in the system; administer palliative care to people in the system and prevent the emergence of a class that would arise and overturn the system was anathema. That lay behind a lot of the resistance.... (Personal communication, January 16, 2016)

Some of the students were also aware of this philosophical tension:

David [Pitt] was the entrepreneur looking for sociology to have relevance in the world like social work and community development. People like Roger Oppenheim and David Bedggood were theorists and purists, and that it was contaminating and denigrating sociology to be associated with social work. When David [Pitt] left it didn't take long for that stream to wash over. (J. Crockett, personal communication, November 27, 2015)

Jones recalled that:

From the first day we were made to understand in no uncertain terms that we were in the sociology department under sufferance. We were not considered to be proper students and the MA [Social Welfare and Development Option II] was not considered to be of any academic respectability. (C. Jones, personal communication, June 15, 2015)

Macpherson recounted that certain people within the Department attempted to work between these ideologies:

Pat Shannon was an absolute radical. Everyone loved and respected Pat. He attempted to bridge the two. In the end even Pat found the going tough. He was a junior lecturer in sociology. He said, "Hold on. While you wait for the revolution there are people in trouble and somebody's got to do something about it. And that's why social work should be given a hearing." (Personal communication, January 16, 2016)

Shannon went on to have a longstanding career at the University of Otago, teaching and researching in, social work, community development and policy.

In 1979, Pitt left the University to pursue a contract working for the United Nations in Geneva, Switzerland. He did not come back as expected. This left another vacancy in an under-resourced department. O'Flaherty described how sociology had been overtaken and swamped by social work with the number of Option II students (those undertaking placements) significantly outnumbering the Option I students-15 in B; only 2 in A (personal communication, May 26, 2016). There were few staff in the Sociology Department available to provide on-going thesis supervision to the social work students. 
In 1974, the NZSWTC produced the "Interim Report on Accreditation", which established minimum standards for a basic professional qualification in social work. This report and accreditation were contentious for the Programme.

In a 1979 (October 8) memorandum for the Vice-Chancellor on the Interim Report of NZSWTC on accreditation, Acting HOD, Vodanovich, wrote that:

The present M.A Option II will not meet the requirements for accreditation. Modification of the course to ensure that it does comply with these requirements means that it will no longer be equivalent to the M. A. in Sociology Option I and not conform to the regulations and academic criteria governing the M.A. degree. (p. 2)

The University of Auckland agreed to suspend enrolments for 1980 and established a sub-committee to review the Social Welfare and Development Course (Tarling, 1980a). At that time, a proposal for a two-year diploma in social work was put forward by Ringwood and Kendrick with an accompanying memo (March 24, 1980) from Vodanovich stating, "We see no reason why a single Department, given the content of such a course, should carry the burden of this new development. An autonomous unit, responsible to all contributing departments would be the ideal solution" (p. 1). In the same memo, Vodanovich made a recommendation to withdraw the MA-Option II.

The sub-committee recommended that the current MA Sociology-Option II should be removed and that the proposed diploma should be "introduced into the Faculty of Arts, with a view to its being taught, if feasible from 1981..." (Tarling, 1980a, p. 2). The sub-committee also noted, however, that the University had limited resources and "[t]hat there must be substantial provision made for the basic training of social workers in other institutions, such as teacher colleges or technical institutes, and that the Social Work Training Council should be urged to take up this question anew" (Tarling, 1980a, p. 2). In a further report on the Department of Sociology, the sub-committee (also chaired by Professor Tarling) refuted the Department's suggestion that a social work programme should not sit within a sociology department.

Despite this recommendation, there was little enthusiasm or resource provided for any particular department to host a social work programme. Kendrick's funding from Mobil Oil finished in 1980, but she remained on staff for a short period in order to help remaining students in the completion of their degrees.

John Crockett, in his role as convenor of the Education and Training Committee of the then New Zealand Association of Social Workers, wrote to the Chancellor of the University of Auckland (November 20, 1979) with several concerns about the course not meeting the new SWTC Accreditation standards: "We as [a] professional body, view the situation as requiring urgent remedy ... we feel it vital to ensure the continuation of the MA course, with suitably qualified, permanent teaching staff as laid down by the Social Work Training Council" (Crockett, 1979, p. 1).

The Vice-Chancellor of the time, C. J. Maiden responded, on November 27, 1979:

There is no possibility at the present time of any specific assurances relating to expansion of course in social work at this University. ... the matter of social work training in Auckland will be looked at in a national context by the University Grants Committee, at the request of this University. (p. 1)

Students were also vocal about the imminent closure and made their voices heard in various ways, targeting various members of the University hierarchy, "I don't think that the Vice-Chancellor appreciated being rung up at home by the students" (I. Vodanovich, personal communication, April 7, 2016). 
Despite these pleas and protests, there was no further intake into the MA Sociology (Option II-Social Welfare and Development) after 1979. The status of the degree as a professional social work qualification was left in limbo, with no accreditation of the degree having occurred during its tenure.

\section{Accreditation}

The New Zealand Social Work Training Council (NZSWTC) was set up in in 1973. Nash (1998) detailed that "The Council's initial priorities were thus to increase the number of courses available; to increase the number of qualified staff and to develop basic minimum standards and a system of accreditation in order to ensure a professional work force" (Minutes of 1st meeting of the NZSWTC, August 7, 1973 cited in Nash, 1998, p. 287).

In 1974 the NZSWTC produced its first draft of basic minimum standards for social work educators (NZSWTC, 1974), and soon after began the contentious process of accrediting social work education providers. ${ }^{1}$ Graduates of accredited programmes would receive a Certificate of Qualification in Social Work (CQSW). Members of the NZSWTC conducted a consultation visit to the University of Auckland in 1976 and a further, informal, visit in 1980. Various recommendations were made regarding the Programme through these visits. In 1981 the NZSWTC was asked by the Department to consider application for accreditation after the Programme had ceased.

The NZSWTC Accreditation Panel consisted of Ian Culpitt, Angela Gilbert, Margaret MacKenzie, Murray Short and Judith MacKenzie. Judith MacKenzie recalled arriving at Auckland where it was clear that there were divisions between those involved in the course and the lecturers in the Sociology Department: "We weren't made to feel particularly welcome. The students were very anxious. They were older, bright and very verbal. Their questions were to the point ... we were aware of the tension" (J. MacKenzie, personal communication, June 12, 2015).
The Panel report took 1979 as its base year for assessment and had concerns regarding the Programme not specifically being housed in a social work department, the lack of social work dedicated staff and some ambiguity regarding formality of placement contracts and assessment. In particular, the Panel noted that:

...there had been no change in title of the course since the previous panel's recommendation. In 1976, "identification of the course with social work education and training" was recommended. It was further recommended that the title of the course, M.A. Sociology (Social Welfare and Development) should not be continued longer than absolutely necessary. The Panel agrees with this original comment, and believes that the title of the degree still does not identify it as a course in social work. The Panel strongly recommends that any future course should contain the term "social work" in its title. (NZSWTC, 1981, pp. 2-3)

This concern was reiterated by one of the students, "It's a shame that my certificate from the University does not say 'Social Work.' It just says 'Sociology Option II'. What the heck is that?" (R. Stewart, personal communication, January 13, 2016).

In the end, the panel found that the course, based on its review of the 1979 year, met the standards required for accreditation (NZSWTC, 1981). This was a very significant development for all of the students in terms of formal recognition of their qualifications. Even with accreditation however, some students experienced difficulties having their qualifications recognised overseas. When attempting to obtain a CQSW in England, students such Goldson (personal communication, August 22, 2015) described difficulties due to perceived lack of fieldwork days, while Jones was told unofficially that he did not qualify due to insufficient social policy content (personal communication, June 15, 2015). 
The course currently sits on Schedule Two, Part 1 of the list of "Historical Recognised New Zealand Social Work Qualifications" on the Social Work Registration Board website. It is referred to as the MA in Sociology (SWRB, 2016).

\section{Contributions of the Programme}

There were many from the Programme who went on to excellent careers in social work, social work education, community work, counselling, research and politics. The Department of Sociology's Annual Report from 1977 states:

One must mention with pride the successes our students, especially those from MA (Option ii) are having in obtaining University or Tertiary Lectureships. These have included recently Ian Shirley (Massey), Pat Shannon (Otago), Dr John Lindsey (James Cook University, Townsville), Peter Harwood (Melbourne), Milton Kayes (Townsville). (1977, p. 1)

In an interesting twist of fate, Susan Kemp, also a graduate from the Programme, has recently returned from the USA to act as Professor in the current University of Auckland social work programmes.

Overall, most students who were interviewed viewed the Programme positively and felt that the combination of a strong sociological orientation and the practicum provided good preparation for a career in social work, "I thought it was an excellent programme overall. It integrated community, social work and counselling as strands of social work. I think today these are seen as something different to social work" (R. Stewart, personal communication, January 13, 2016).

\section{Discussion and conclusion}

Soon after the discontinuation of the MA-Option II, a basic qualifying two-year diploma began at the Auckland Teachers' College. This eventually turned into a three-year degree programme, and then a four-year degree programme. The Auckland College of Education merged with the University of Auckland in 2004. Thirty years after the MA Sociology (Option II-Social Welfare and Development) closed its intake, the University of Auckland approved a twoyear, professional Master's degree in social work which began in 2010.

Many of the issues described in this article remain current in social work education. Practicum experiences remain difficult to locate and manage; there are often challenges in having enough supervisors to supervise research and social work programmes continue to experience difficulties due to their Tertiary Education Commission funding levels being funded at the same level as other non-professional social science programmes (Beddoe, 2014).

One remarkable issue, however, is the difference between then and now in terms of recognition and acknowledgement of Māori as Tangata Whenua, Te Tiriti o Waitangi and of social work's bicultural commitments. The Programme was winding down as the Māori Renaissance began (Eketone \& Walker, 2016). The revised 1976 version of the NZSWTC's Minimum Standards for an Accredited Course in Social Work, makes mention only of inclusion of study "of plural societies with particular reference to New Zealand" (NZSWTC, 1976, p. 5) and makes no mention of Te Tiriti o Waitangi. The winds of change were coming, however, and social work education would change dramatically in the 1980s and further thereafter.

While this article has in no way presented an exhaustive account of the Programme, and there are many staff and students' voices that have not been represented, it has attempted to synthesise some descriptions, documents and recollections regarding the brief-lived Auckland MA Sociology (Option II-Social Welfare and Development). It is hoped that it has provided a rich description of the Programme and some analysis of why it survived for such a short time. 


\section{Note}

i The NZSWTC did not accredit a community work programme being provided by the YMCA which further contributed to a growing divide of academic and community orientations of the profession. For a full account, see Nash's 1998 thesis.

\section{Acknowledgements}

The author would like to acknowledge the memory of June Kendrick and her contribution to this article as well as all other participants who gave generously of their knowledge and time.

\section{References}

Beddoe, L. (2014). A matter of degrees: The role of education in the professionalisation journey of social work in New Zealand. Aotearoa New Zealand Social Work, 26(2/3), 17-28.

Bryman, A. (2016). Social research methods (5th ed.). London, England: Oxford University Press.

Cranna, J. (1989). Towards bicultural development: A history of pioneering school of social work at the Auckland College of Education 1980-1988. Auckland, New Zealand: Auckland College of Education.

Crockett, J. (1977). Social work education in New Zealand (Unpublished master's thesis). University of Auckland New Zealand.

Department of Sociology, University of Auckland. (1976) Annual report, 1976. Auckland, New Zealand: Author.

Department of Sociology, University of Auckland. (1977). Annual report, 1977. Auckland, New Zealand: Author.

Department of Sociology, University of Auckland. (1978). Annual report, 1978. Auckland, New Zealand: Author.

Department of Sociology, University of Auckland. (1979a). Annual report, 1979. Auckland, New Zealand: Author.

Department of Sociology, University of Auckland. (1979b). Course outline 82.500 Principles of social work. Auckland, New Zealand: Author.

Eketone, A., \& Walker, S., (2016). Kaupapa Māori social work research. In M. Gray, J. Coates, M. Yellow Bird, \& T. Heterington (Eds.), Decolonizing social work (pp. 259-270) Oxon, England: Routledge.

Harington, P. (2016). Sociology and social work in New Zealand. New Zealand Sociology, 31(3), 110-145.

Kendrick J. (1979). Memorandum to I. Ivonovich (November 13, 1979). Files of June Kendrick in the possession of Barbara Staniforth

Maiden, C. J. (1979). Letter to J. Crockett. (November $27,1979)$. Files of June Kendrick in the possession of Barbara Staniforth

McCreary, J. (1971a). The School of Science: Part one: The martians. The New Zealand Social Worker, 7(1), 9-17.
McCreary, J. (1971b). The School of Science:

Part two: The minions. The New Zealand Social Worker, 7(2), 41-50.

McDonald, D. (2004). The predestined choice: Social work education and ANZASW. Social Work Review, 16(4), 13-21.

Nash, M. (1998). People, policies and practice. Social work Education in Aotearoa/ New Zealand from 1949-1995 (Unpublished doctoral dissertation). Massey University, Palmerston North, New Zealand.

Nash, M. (2001). Social work in Aotearoa New Zealand: Its origins and traditions. In M. Conolly (Ed.), Social work in New Zealand. Contexts and practice (pp. 32-43). Auckland, New Zealand: Oxford University Press.

New Zealand Social Work Training Council. (1974). Minimum standards for an accredited course in social work. Wellington, NZ: Department of Social Welfare.

New Zealand Social Work Training Council. (1976). Minimum standards for an accredited course in social work (revised 1976). Wellington, NZ: Department of Social Welfare.

New Zealand Social Work Training Council Accreditation Advisory Panel (1981). Report on the Auckland University Course for the Degree of Master of Arts Sociology (Option II: Social Welfare and Development). Wellington, NZ: Author.

Pitt, D. (1979). Guidelines for students. MA (Social Welfare and Development). Auckland, New Zealand: University of Auckland.

Social Work Registration Board. (2016). Historical recognised social work qualifications. Wellington, New Zealand: Author. Retrieved from http://www.swrb.govt.nz/newapplicants/recognised-qualifications

Staniforth, B. (2010). Past, present, and future perspectives on the role of counselling in social work in Aotearoa New Zealand (Unpublished doctoral dissertation). Massey University, Auckland, New Zealand.

Staniforth, B., \& Nash, M. (2012). Bringing a myriad of gifts: June Kendrick. Aotearoa New Zealand Social Work, 24(2), 27-37.

Staniforth, B. L. (2015). Tiromoana and Taranaki House: A tale of their times. Aotearoa New Zealand Social Work Review, 27 (1-2), 5-23.

Tarling, N. (1980a). Report to academic committee: Social welfare and development and related matters. Auckland, New Zealand: University of Auckland. Retrieved from University of Auckland Library archives.

University of Auckland. (1977). University of Auckland calendar 1977. Auckland, New Zealand: Author.

van Heugten, K., \& Gibbs, A. (2015). Overview of the historical and contextual development of sociology and social work. In K. van Heugten \& A. Gibbs (Eds.), Social work for sociologists: Theory and practice (pp. 9-25). New York, NY: Palgrave Macmillan.

Vodanovich, I. (1979). Memorandum for the Vice-Chancellor. October 8, 1979. Files of June Kendrick in possession of Barbara Staniforth.

Vodanovich, I. (1980). Memorandum to Professor P. N. Tarling, Convenor Sub-Committee of Academic Committee. March 24, 1980. Files of June Kendrick in possession of Barbara Staniforth. 